\title{
Effects of large enemies on success of exotic species in marine fouling communities of Washington, USA
}

\author{
Erin K. Grey* \\ Department of Ecology and Evolutionary Biology, The University of Chicago, 1101 E. 57th St., Chicago, Illinois 60637, USA \\ Present address: Department of Ecology \& Evolutionary Biology, Tulane University, Boggs 400, New Orleans, \\ Louisiana 70118, USA
}

\begin{abstract}
The enemy release hypothesis, which posits that exotic species are less regulated by enemies than native species, has been well-supported in terrestrial systems but rarely tested in marine systems. Here, the enemy release hypothesis was tested in a marine system by excluding large enemies $(>1.3 \mathrm{~cm}$ ) in dock fouling communities in Washington, USA. After documenting the distribution and abundance of potential enemies such as chitons, gastropods and flatworms at 4 study sites, exclusion experiments were conducted to test the hypotheses that large grazing enemies (1) reduced recruitment rates in the exotic ascidian Botrylloides violaceus and native species, (2) reduced $B$. violaceus and native species abundance, and (3) altered fouling community structure. Experiments demonstrated that, as predicted by the enemy release hypothesis, exclusion of large enemies did not significantly alter B. violaceus recruitment or abundance and it did significantly increase abundance or recruitment of 2 common native species. However, large enemy exclusion had no significant effects on most native species or on overall fouling community structure. Furthermore, neither B. violaceus nor total exotic species abundance correlated positively with abundance of large enemies across sites. I therefore conclude that release from large enemies is likely not an important mechanism for the success of exotic species in Washington fouling communities.
\end{abstract}

KEY WORDS: Enemy release hypothesis $\cdot$ Fouling community $\cdot$ B. v. $\cdot$ Botrylloides violaceus Resale or republication not permitted without written consent of the publisher

\section{INTRODUCTION}

Enemies such as predators and parasites are key players in many ecological systems. They can regulate the populations directly via mortality (Huffaker et al. 1970, Crawley 1989, Hanski et al. 1991, Hixon \& Carr 1997) or indirectly via apparent competition (Holt 1977), and can promote diversity in competitive communities (Tansley \& Adamson 1925, Paine 1974, Lubchenco 1978). With respect to exotic species, enemies are the focus of a popular hypothesis of invasion success: the 'enemy release' hypothesis (Darwin 1859, Elton 1958, Williamson 1996, Mack et al. 2000, Keane \& Crawley 2002, but see Colautti et al. 2004 for a critique of a simplistic interpretation of enemy release).
This hypothesis posits that exotic species escape from their native enemies when they enter a novel range. These 'released' populations can then grow quickly, spread to more locations, and have a competitive advantage over native species that are controlled by native enemies. The enemy release hypothesis has been supported in terrestrial plant studies that have quantified predator impacts on exotic and native species (Liu \& Stiling 2006, but see Agrawal \& Kotanen 2003) and in studies that compared predator and pathogen effects on native and exotic populations of the same species (Wolfe 2002, Mitchell \& Power 2003).

In contrast to terrestrial systems, the enemy release hypothesis has only been investigated in a few marine systems; 3 laboratory experiments found that predator 
preferences support the enemy release hypothesis: (1) Gollan \& Wright (2006) found that native grazers preferred native algal species over the exotic Caulerpa taxifolia in a southern Australian estuary, (2) Simoncini \& Miller (2007) demonstrated that the native urchin Stronglyocentrotus droebachiensis preferred to graze a native ascidian Aplidium glabrum over the exotic ascidian Botrylloides violaceus in the Gulf of Maine, (3) Epelbaum et al. (2009) found that a variety of predators preferred native ascidian species over the exotic ascidians B. violaceus and B. schlosseri in British Columbia. Results consistent with the enemy release hypothesis were also found in 2 studies where parasite loads were lower in exotic populations of mobile marine organisms: Torchin et al. (2002) reviewed 9 species (3 crab, 4 gastropod, 1 echinoderm, 1 ctenophore), and Vignon et al. (2009) compared exotic and native populations of the peacock grouper, Cephalopholis argus. However, 2 studies have found evidence contrary to the enemy release hypothesis. Shinen et al. (2009) found that whelks preferred the exotic mussel Mytilus galloprovincialis over native congeners $M$. californianus and $M$. trossulus, and that the survival of $M$. galloprovincialis was lower than that of $M$. californianus when out-planted to the intertidal, presumably due to whelk predation. Finally, Strong et al. (2009) used field observations and lab studies to show that grazing and epiphytism affected the exotic kelp Sargassum muticum as much as native algal species in Northern Ireland.

Overall from the literature, enemy release does not appear to be a consistently important mechanism for success in marine exotic species. With the exception of Shinen et al. (2009) and Strong et al. (2009), previous studies have been conducted in the lab and lack experimental demonstration of 2 requisites of the enemy release hypothesis: (1) an exotic species is more limited by enemies in its native range than in its new range, and (2) enemies limit native species to a greater extent than they do exotic species. Here I tested the second requisite of the enemy release hypothesis using dock fouling communities in Washington, USA that have been invaded by an exotic colonial ascidian, Botrylloides violaceus.

Enemy release can be a major determinant of exotic species success in marine fouling communities because of the central role of enemies in community development and structure. Grazing by large organisms such as chitons, gastropods, nudibranchs, echinoderms, and fish can reduce the post-settlement survival of some species (Stoner 1990, Osman et al. 1992, Osman \& Whitlatch 1995, Hunt \& Scheibling 1997), which can alter community development (Nydam \& Stachowicz 2007) and ultimately the structure of mature fouling communities (Sutherland 1974, Vance
1988, Karlson 1978, Osman \& Whitlatch 2004, but see Keough \& Butler 1979, Connell 2001, Sams \& Keough 2007). Fouling communities on anthropogenic substrates such as docks and pilings often harbor many exotic species because of their association with shipping, a major vector of exotic marine species (Ruiz \& Carlton 2003, Molnar et al. 2008), but the effects of native enemies to these species are poorly studied.

Botrylloides violaceus, an ascidian believed to be native to Japan (Lambert \& Sanamyan 2001), has become a particularly successful exotic species that now occurs circumglobally in temperate waters. In Washington, USA, where it has occurred for over $25 \mathrm{yr}$, $B$. violaceus was found underneath floating docks at all sites surveyed in 2005 (10 sites; Grey 2009a), thus providing an opportunity to understand the role of enemy release in the success of this species across a range of sites. I tested the enemy release hypothesis by testing the effect of large-enemy exclusion on $B$. violaceus abundance, native species abundance and fouling community structure. I expected that exclusion of large enemies would have either no effect on $B$. violaceus recruitment and abundance or a negative effect due to apparent competition, a large positive effect on native species recruitment and abundance, and consequently, a significant effect on the overall structure of the communities.

\section{MATERIALS AND METHODS}

Diversity and abundance of enemies in fouling communities. I first compared the assemblages of enemies at 4 study sites by quantifying enemy presence and abundance on settlement plates. In June 2005, 24 settlement plates $(24 \times 24 \mathrm{~cm}$ acrylic, sanded with an electric grinder and coarse sandpaper) were deployed at each site, and sessile fouling species quickly settled and grew on these plates. Plates were spaced $15 \mathrm{~cm}$ apart and placed horizontally with their backs against the dock's bottom substrate so that benthic enemies were able to move onto the plates. Sites were chosen to represent the range of salinity, temperature and species diversity values in the region (see Grey 2009b for site details). Briefly, Makah and Lopez were more oceanic sites with lower temperatures, higher salinities and higher diversity, while Wayne had higher temperatures and lower diversity, and Pleasant had the highest temperatures, lowest salinities and lowest diversity.

To estimate enemy abundance at each site, I recorded the presence of enemies visible to my eye on plates every $2 \mathrm{wk}$ in the summer (May to September) and once during mid-December for 2 years (2006 and 2007). To do this, I removed the plates from underneath the docks and counted the number and type of 
enemies on each plate and measured individual lengths when possible. Highly mobile enemies such as fish and crabs likely escaped the plates as they were being removed and could thus not be quantified. However, benthic enemies such as chitons, gastropods, nudibranchs and echinoderms could be counted with this method. I then placed enemy species into 3 functional groups (large mollusks, small mollusks and flatworms, see Supplement 1; available at www.int.res. com/articles/suppl/m411p089_supp.pdf) and calculated the abundance (ind. plate ${ }^{-1}$ census $^{-1}$ ) of each group for each site. Briefly, functional groups were used because the exact diets of many enemies are either very broad or currently unknown. Size and feeding apparatus correlate with diet (Steneck \& Watling 1982), and thus indicate the type of predation on fouling organisms at each site.

Bull-dozing and predation by large mollusks, because of their larger size, could potentially have large effects on populations and communities of fouling species. Thus, I used this as a metric of enemy pressure across sites, with the caveat that smaller enemies or other large predators, such as sea urchins and fish, could have large effects as well. To measure the mortality-pressure exerted by large mollusks at each site, I calculated total mean large mollusk biomass for each site ([ind. plate ${ }^{-1}$ census $\left.^{-1}\right] \times$ mean individual length).

Effect of large enemies on Botrylloides violaceus and the fouling community. To test the effect of large enemies on $B$. violaceus success, native species success and fouling community composition, I conducted 2 exclusion experiments at each study site: one experiment tested the effect of large enemies on species recruitment rates and the other on species abundance and fouling community composition. For both experiments, enemies $>1.3 \mathrm{~cm}$ (including large mollusks, echinoderms, crabs and fish but not small mollusks or flatworms) were excluded from settling plates by affixing $1.3 \mathrm{~cm}^{2}$ vinyl-coated wire mesh cages over the plates. These cages were effective in excluding mollusks $>1.3 \mathrm{~cm}^{2}$ (pers. obs.), but smaller mollusks were occasionally found on the caged plates and were removed at every census. Cage-control treatments were used to test for cage artifacts, which could have included larval responses to cage material or alteration of small-scale hydrodynamics (Underwood 1997). Cage-controls consisted of the mesh affixed onto the corners of 2 sides of a plate. Control plates were left uncovered.

To test the effects of large enemy exclusion on species recruitment rates at each site, I counted the number of new recruits on plates ( 3 treatments $\times 8$ replicates $=24$ total) that were scraped clean of invertebrates after each census. I then calculated the recruitment rate at each census (ind. plate ${ }^{-1} \mathrm{~d}^{-1}$ ). To test for large enemy effects on species abundance and overall community structure at each site, I recorded the presence and abundance (no. of individuals) of fouling species on un-scraped plates (3 treatments $\times 8$ replicates $=24$ total) every $2 \mathrm{wk}$ from June to September 2005 and once in December 2005. To census a plate, I pulled it out of the water, overlaid a grid with $4 \times 4 \mathrm{~cm}$ sub-samples, recorded the number of individuals of each species visible to my eye in 6 random sub-samples, and then re-deployed the plates. If individuals occupied more than one sub-sample, they were counted only once. It was difficult to discern individuals of species that formed aborescent structures connected via stolons. For these species (bryozoans Bowerbankia gracilis, Bugula sp., Dendrobeania lichenoides and hydroid Obelia sp.), I counted the number of aborescent structures instead.

I chose to use number of individuals as a metric for abundance because mortality occurs at the level of the individual. However, many fouling species are colonial and partial mortality of colonies could influence their reproductive success. Thus, during each census I also counted the number of Botrylloides violaceus colonies in each of 2 size classes: small ( $<100$ zooids) and large ( $>100$ zooids). This provided a coarse test of largeenemy effects on the size of $B$. violaceus colonies.

Statistical analyses. To test the null hypothesis that large mollusk biomass, and therefore grazing pressure, was similar among sites, I conducted a 1-way ANOVA with 'Site' as a fixed factor.

Large enemy exclusion effects on species recruitment rates and abundance (no. of individuals) at each site were tested with a repeated-measures ANOVA with Plate as a random effect. A species was first classified as either exotic or native according to Cohen (2004). Then, because the fouling communities were very diverse (27 to 39 species) and because data on rare species was non-normal, I report tests on the 2 most common native species at each site. These species were found by ranking the species by number of individuals recorded at each site over the course of the experiment. The 2 most abundant native species were the colonial hydroid Obelia sp. (60.1\% of total individuals) and the colonial ascidian Distaplia occidentalis $(7.4 \%)$ at Makah, D. occidentalis $(16.4 \%)$ and the solitary ascidian Corella inflata $(14.9 \%)$ at Wayne, the mussel Mytilus trossulus (3.4\%) and C. inflata (1.7\%) at Pleasant, and C. inflata $(11.7 \%)$ and D. occidentalis $(5.8 \%)$ at Lopez. For species that were only present at certain times of the year, I used data from census dates where at least 1 individual was present for statistical analyses. To meet the assumption of normality for ANOVA tests, I log-transformed all data, except for $C$. inflata abundance at Wayne, which required squareroot transformation. 
The results for all other exotic species and the 8 most common native species at each site are presented in Supplement 2 (available at www.int-res.com/articles/ suppl/m411p089_supp.pdf). Consideration of these additional species did not change my overall conclusions on the importance of enemy release to exotic species success.

To test the effects of cage treatment on Botrylloides violaceus colony size, I calculated the mean number of small and large colonies on each plate over time and conducted a 1-way ANOVA. This statistical method was chosen in place of repeated-measures ANOVA on raw data because the large colony data had many zeros and were difficult to normalize. Data on mean number of large colonies at all sites and mean number of small colonies at Makah were log-transformed.

To test caging and site effects on community composition, I used analysis of similarities (ANOSIM), which is a non-parametric test of differences between groups of dissimilarity matrices. Bray-Curtis dissimilarity matrices were calculated from species-abundance data from the final summer census of the uncleared plates (914 September 2005) for the ANOSIM. The Bray-Curtis index was chosen because it provides a robust monotonic measure of distance between communities (Faith et al. 1987). To visualize large enemy effects on community composition, I used non-metric multidimensional scaling (nMDS) to ordinate the data at 2 scales: (1) To see whether enemies caused a general shift in community composition, I ordinated dissimilarities of data pooled across all 4 sites, and then (2) to see whether the large enemy effect was sitespecific, I ordinated dissimilarities within each site.

Finally, to test whether large enemy abundance was associated with higher relative abundance of exotic species, I correlated mean large mollusk biomass with both the relative abundance of Botrylloides violaceus and the relative abundance of all exotic species. A 1-tailed test was used to assess the significance of this correlation. All statistical analyses were performed in the $\mathrm{R}$ programming language (www.R-project.org), and community composition analysis was conducted with the Vegan package (Oksanen et al. 2009).

\section{RESULTS}

\section{Diversity and abundance of enemy species across sites}

Enemy functional group abundance and large mollusk biomass varied significantly among sites (Fig. 1). Overall, enemies were most abundant at Makah, which had more large mollusks and flatworms than did any other site. Large mollusks and flatworms were notably less abundant at Lopez and Pleasant, whereas small mollusks were less abundant at Wayne. Large mollusk biomass varied among sites as well (1-way ANOVA, p < 0.001), and was highest at Makah, where it was roughly double that of the next highest site, Wayne (Fig. 1b). Large mollusk biomass was lowest at Lopez, which had both the lowest abundance and the smallest mean size of large molluskan grazers. To the best of my knowledge, all of the observed predator species are considered native to the study region.

\section{Caging effects on recruitment and abundance in Botrylloides violaceus and native species}

Botrylloides violaceus and native species recruitment rates varied by Site and census date (Date) (Fig. 2, Appendix Table A1). Caging treatment had a significant effect on recruitment rates of the native ascidian Corella inflata at Lopez (Table A1k, p=0.002), with recruitment being higher on caged plates. Otherwise, caging treatment did not have a significant effect on any other native species or $B$. violaceus (Table 1). Cage Trt $\times$ Date interaction effects were insignificant for every species at every site. These results suggest that grazing by large enemies did not significantly inhibit recruitment of most fouling species.

Botrylloides violaceus and native species abundance also varied by site and by census date (Fig. 3). Again there was no significant effect of caging-treatment on B. violaceus abundance at any site (Table A1m, $\mathrm{p}, \mathrm{s}, \mathrm{v}$ ). There was, however, a significant Cage Trt $\times$ Date effect on $B$. violaceus abundance at Lopez $(p=0.001$, Table A1v). Inspection of model coefficients revealed 2 significant differences between cage and control plates on the dates of July 28 and December $12\left(^{*}\right.$ in Fig. 3v); however, the differences were not in the same direction. On July 28, B. violaceus abundance was higher in caged plates, while on December 12, it was significantly lower than in the control treatment. Aside from these 2 instances, I found no evidence that cage treatment influenced the number of $B$. violaceus at any of the study sites. There was also no significant effect of enemy exclusion on the mean abundance of large and small B. violaceus colonies at any site (Appendix Table A2).

Large enemy exclusion effects on native species abundance were significant for only 2 species. At Makah, which had the highest large mollusk biomass, the most common native species, Obelia sp., was significantly more abundant in the cage treatment $(\mathrm{p}=$ 0.041, Table A1n, Fig. 3n). At Wayne, the site with the second highest large mollusk biomass, the abundance of the second most common native species, Corella inflata, was significantly higher on caged plates $(\mathrm{p}=$ 

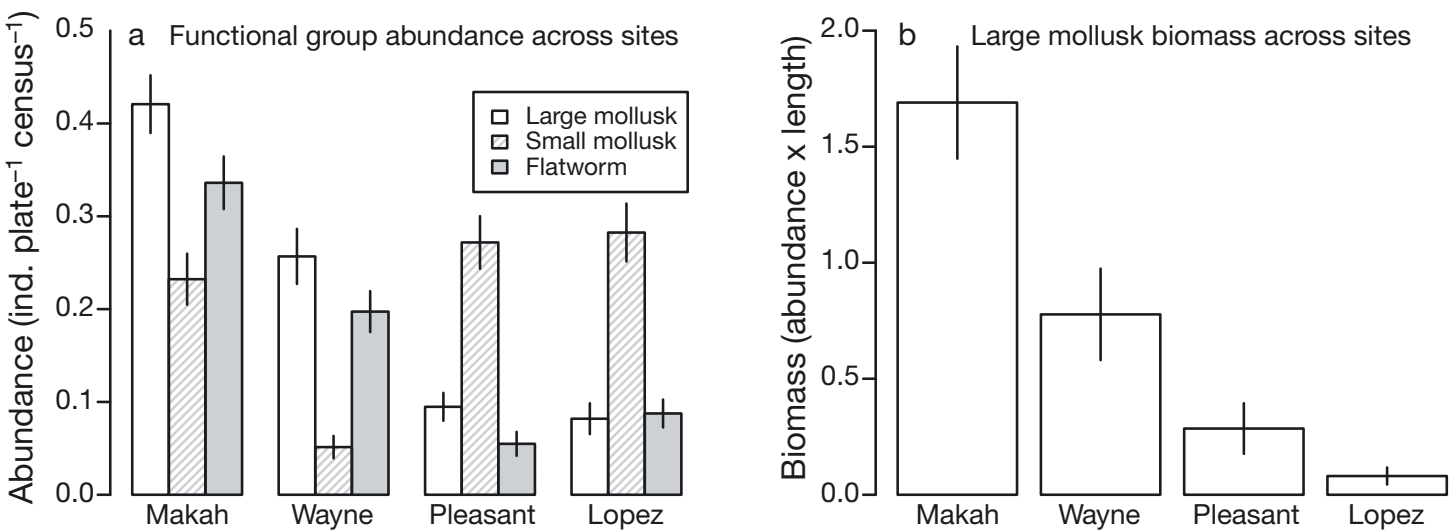

Fig. 1. Abundance of enemy species across study sites, quantified as (a) functional group abundance and (b) large mollusk biomass (mean \pm SE). See Supplement 1 at www.int-res.com/articles/suppl/m411p089_supp.pdf for functional groups. Per site, mean biomass was found by averaging across 20 to 24 plates. Variation in large mollusk biomass is statistically significant (1-way ANOVA, $\mathrm{p}<0.0001)$
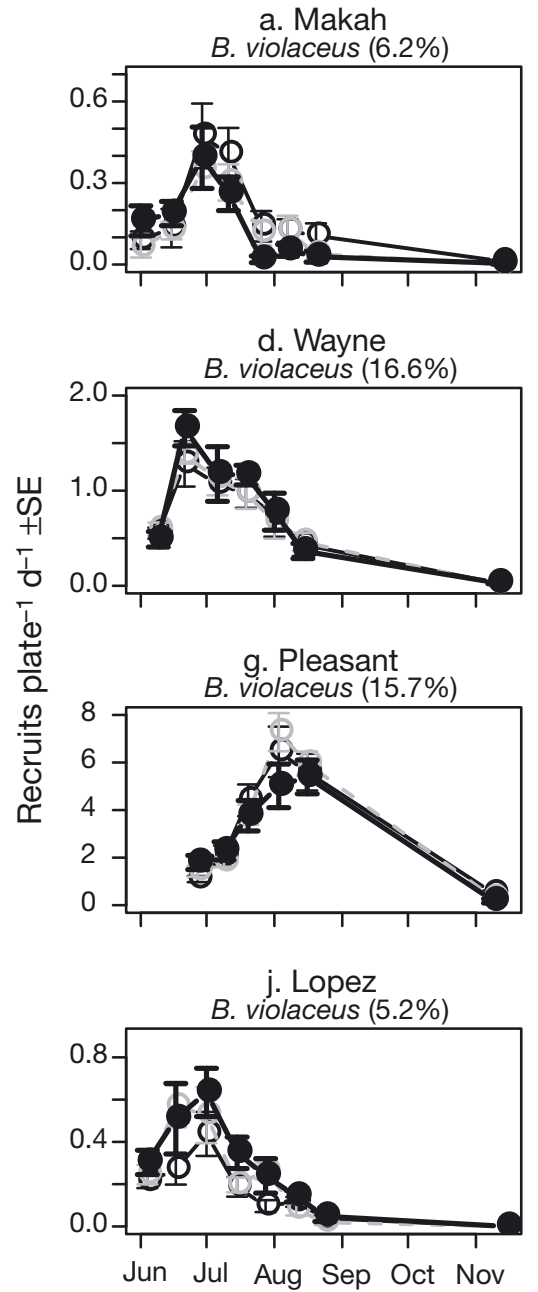

b. Makah 1st native Obelia sp. $(60.1 \%)$

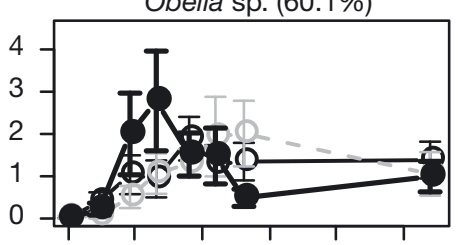

e. Wayne 1st native

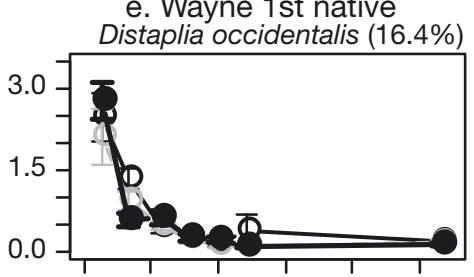

h. Pleasant 1st native Mytilus trossulus (3.4\%)

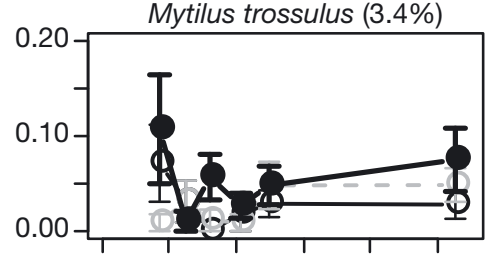

k. Lopez 1st native Corella inflata $(11.7 \%)$

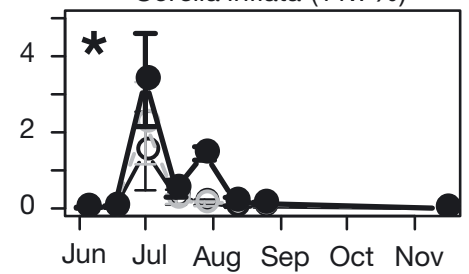

c. Makah 2nd native Distaplia occidentalis (7.4\%)
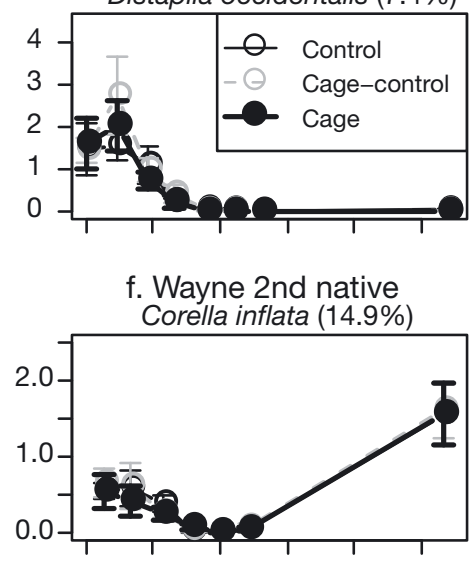

i. Pleasant 2nd native Corella inflata $(1.7 \%)$

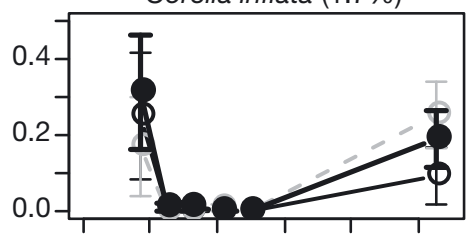

I. Lopez 2nd native

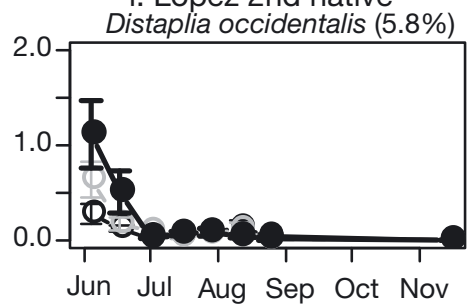

Fig. 2. Botrylloides violaceus and native species recruitment rates (recruits plate ${ }^{-1} \mathrm{~d}^{-1}$, mean \pm SE) across study sites. Treatments: control $=0$, cage-control $=0$, cage $=\bullet$. * Significant Cage Treatment effects 

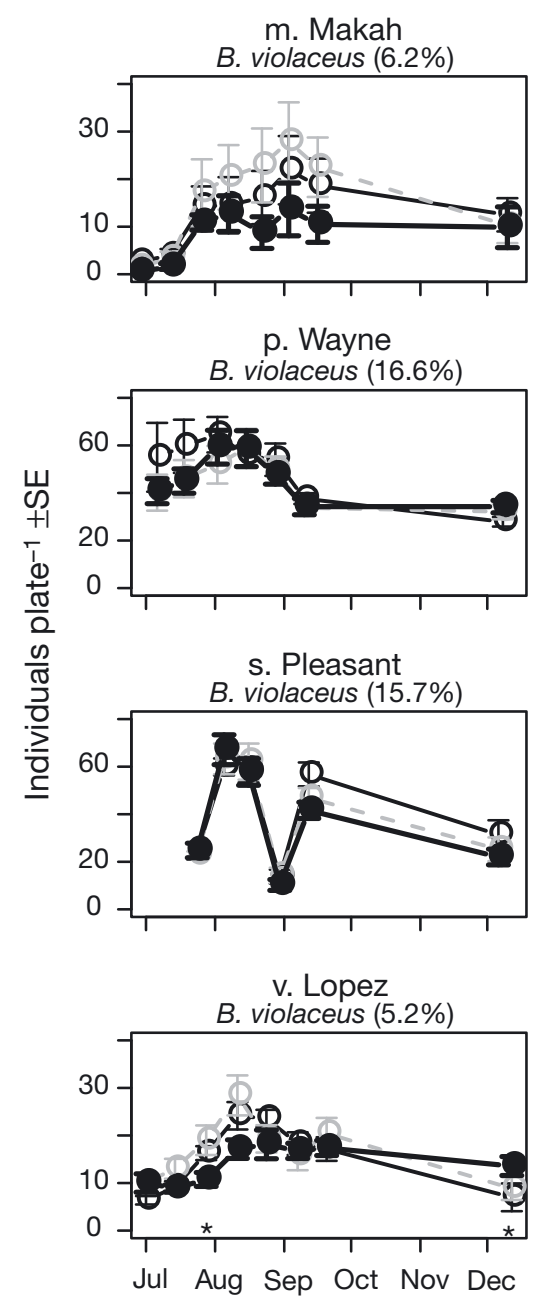

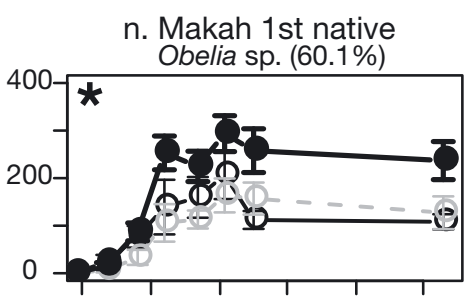

q. Wayne 1st native

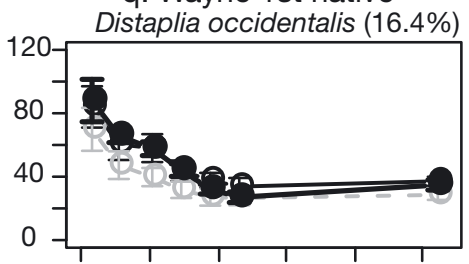

t. Pleasant 1 st native

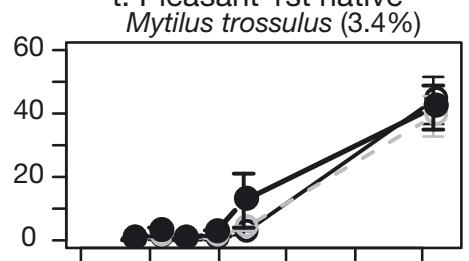

w. Lopez 1st native Corella inflata $(11.7 \%)$

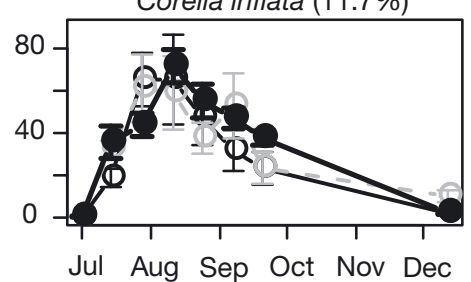

o. Makah 2nd native

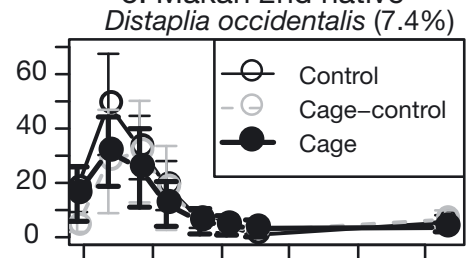

r. Wayne 2nd native

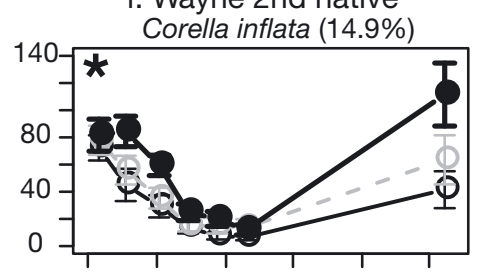

u. Pleasant 2nd native Corella inflata $(1.7 \%)$

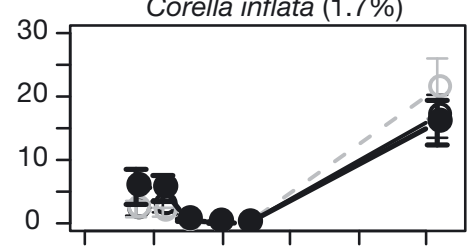

x. Lopez 2nd native Distaplia occidentalis (5.8\%)

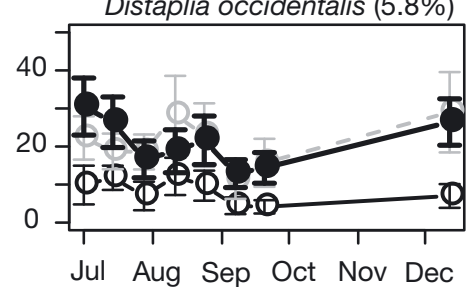

Fig. 3. Botrylloides violaceus and native species abundance (ind. plate ${ }^{-1}$, mean \pm SE) across study sites. Treatments: control $=0$, cage-control $=0$, cage $=\bullet$. * Significant Cage Treatment $($ Trt $)$ effects. * Significant Cage Trt $\times$ Date effects

0.029, Table A1r, Fig. 3r). At the 2 sites with the lowest large mollusk biomass, Pleasant and Lopez, caging treatment had no significant effects on either of the 2 most common native species (Table $\mathrm{A} 1 \mathrm{t}, \mathrm{u}, \mathrm{w}, \mathrm{x}$, Fig. 3t, $u, w, x)$. Cage Trt $\times$ Date interactions were not significant for any native species (Table A1). These results show that large enemies can reduce the abundance of common native species, but only where large enemies are abundant.

\section{Large enemy effects on fouling community structure}

Ordination of community dissimilarities revealed 2 distinct patterns in Washington fouling communities. (1) Plate communities from the same site clustered together forming distinct groups that had little or no overlap with other sites (Fig. 4a); (2) caging effects on community structure were not apparent either gener- ally across sites (Fig. 4b) or specifically within each site (Fig. 5a-d). ANOSIM results corresponded to this visual pattern: community composition significantly varied with Site $(\mathrm{p}<0.001)$ but not by Cage Trt $(\mathrm{p}=$ $0.098)$ or Cage Trt $\times$ Site $(p=0.149)$ (Table 1$)$. Only analysis of the September 2005 censuses is presented here, but this result was found for all census dates except for the late August date, when there was a significant Site $\times$ Cage Trt effect (data available upon request). Overall, this analysis suggests that sites harbor distinct fouling communities whose composition is not strongly influenced by large enemies.

\section{Correlations of large mollusk biomass and relative exotic abundance}

Correlations between mean large mollusk biomass and Botrylloides violaceus relative abundance (Pear- 

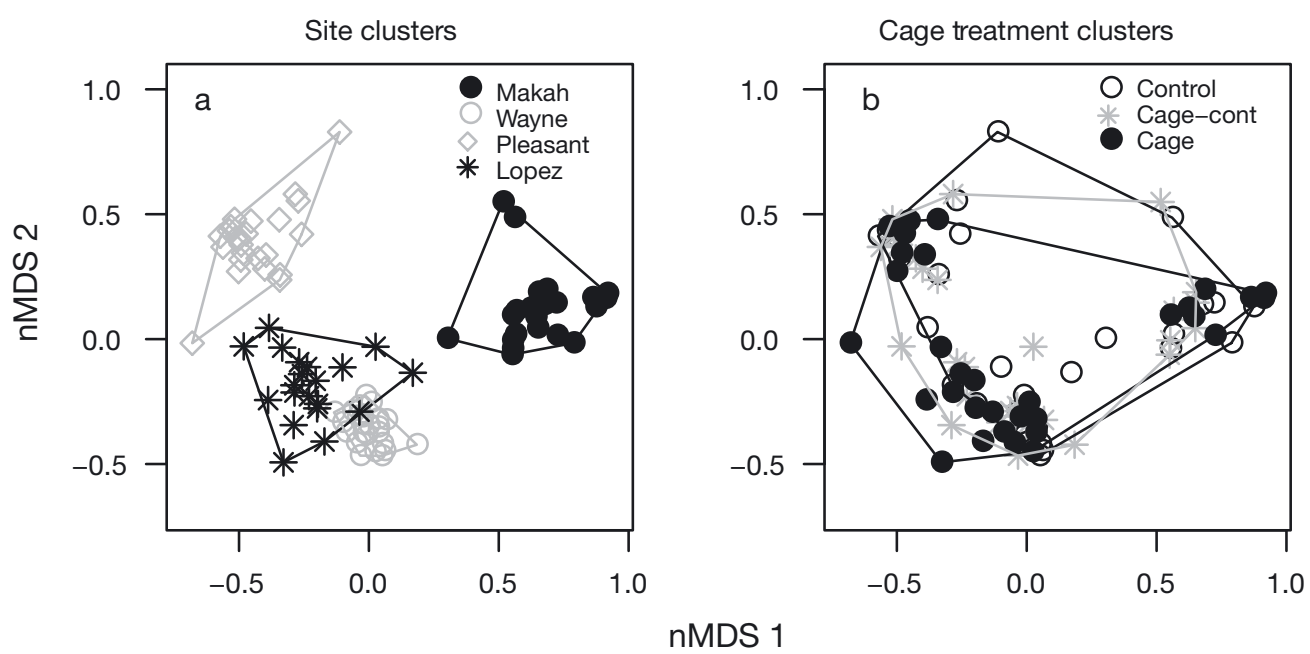

Fig. 4. Ordination of community dissimilarities across sites. Species abundance data were ordinated using non-metric multidimensional scaling (nMDS) of Bray-Curtis dissimilarity matrices calculated from data pooled across sites (stress $=0.127$ ). Points represent plates, and variation in point types corresponds to different (a) sites and (b) caging-treatments. Data in plots is otherwise identical. To aid in visualization, lines are drawn around all points in each group
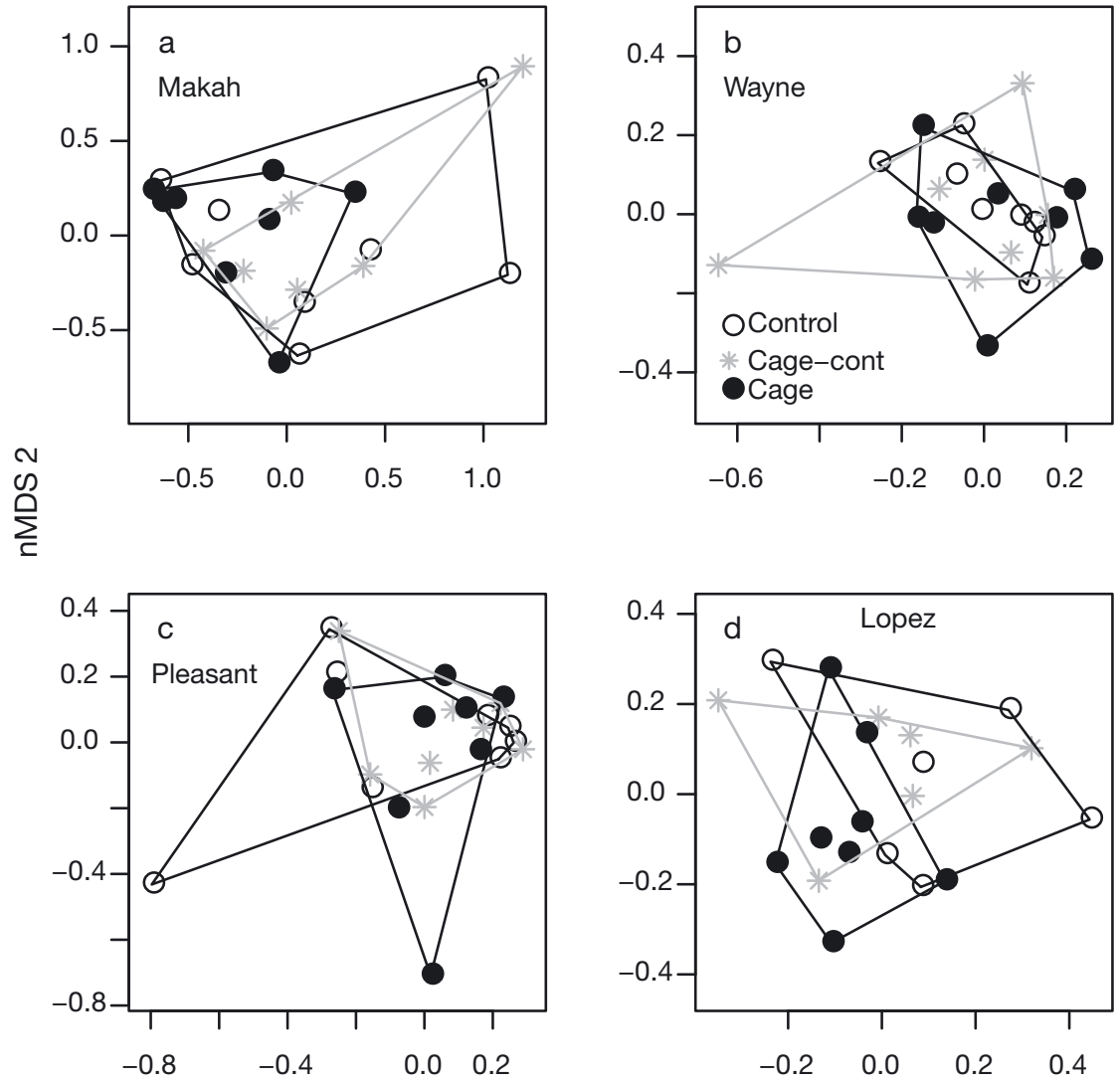

nMDS 1

Fig. 5. Ordination of community similarities within each site. Community data within each site were ordinated using non-metric multi-dimensional scaling (nMDS) of Bray-Curtis dissimilarity matrices calculated independently for each site: (a) Makah

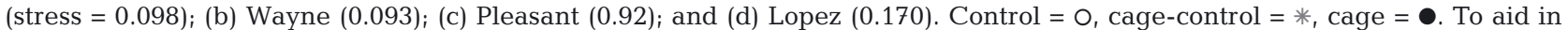
visualization, lines are drawn around all points in each group 
Table 1. ANOSIM of community data

\begin{tabular}{|lrrrrrc|}
\hline Effect & df & SS & MS & $F$ & $\mathrm{R}^{2}$ & $\mathrm{p}$ \\
\hline Site & 3 & 18.76 & 6.25 & 70.26 & 0.702 & $<0.001^{* * *}$ \\
Cage Trt & 1 & 0.17 & 0.16 & 1.89 & 0.006 & 0.098 \\
Site $\times$ Cage Trt & 3 & 0.39 & 0.13 & 1.47 & 0.015 & 0.149 \\
Residuals & 83 & 7.4 & 0.9 & & 0.277 & \\
Total & 90 & 26.7 & & & 1 & \\
\hline
\end{tabular}

son's correlation coefficient $=-0.21, p=0.79$ ) and between mean large mollusk biomass and the relative abundance of all exotic species (Pearson's correlation coefficient $=-0.95, \mathrm{p}=0.06$ ) were non-significant and in the direction opposite of that predicted by enemy release hypothesis. Thus, across sites, there is no evidence that release from large enemies is associated with increased exotic species success.

\section{DISCUSSION}

Experimental results demonstrated that large enemies do not significantly limit populations of the exotic Botrylloides violaceus at any study site. Even at the site with the highest large mollusk biomass, Makah, I found no evidence that large enemy exclusion significantly affected $B$. violaceus recruitment rates or colony abundance. Furthermore, it does not appear that large enemies affected the size of $B$. violaceus colonies, although the 2 size classes used in this experiment were coarse measures of size and a finer-scale test is warranted.

Despite the result that large enemies did not greatly limit Botrylloides violaceus populations, there was little evidence that release from large enemies was an important mechanism explaining this exotic species' success in Washington fouling communities. First, $B$. violaceus recruitment and abundance were not enhanced when large enemies were present, which would be expected if it had gained a competitive edge over enemy-prone native species. Also, large enemies limited the recruitment of only 1 native species at 1 site (Corella inflata at Lopez) and the abundance of just 2 native species, Obelia sp. and $C$. inflata, at 2 sites with high levels of large mollusk biomass, Makah and Wayne. At sites with less large mollusk biomass, Pleasant and Lopez, I found no significant effect of large enemy exclusion on the abundance of the 2 most common native species. Excluding large enemies did not alter community structure at any of the sites, indicating that indirect effects of predation through apparent competition are likely to be small. Finally, overall, large mollusk biomass across sites did not positively correlate with the relative abundance of either $B$. violaceus abundance or total exotic species. I therefore conclude that release from large enemies is not an important mechanism explaining $B$. violaceus success.

The result that large enemies do not have significant impacts on Washington fouling communities is surprising, given that previous studies have found very strong effects of such enemies in similar habitats (Sutherland 1974, Vance 1988, Karlson 1978, Osman \& Whitlatch 2004, Nydam \& Stachowicz 2007, but see Keough \& Butler 1979, Connell 2001 and Sams \& Keough 2007 for results similar to this study). There are 3 potential explanations for this result. (1) The statistical power may have been too low to detect significant effects amidst the inherent spatial and temporal variability of these very dynamic communities. (2) Micro-predators or parasites, which were not manipulated in this experiment, could limit fouling species to a greater extent than do large enemies. (3) The inverted nature of subtidal floating dock habitats may reduce the abundance of important enemies such as sea urchins that cannot attach themselves to these substrates. I consider these possibilities below.

I conducted post-hoc power analysis to evaluate this experiment's ability to detect significant caging effects on Botrylloides violaceus and native species abundance at each site at each census date (Supplement 3 ; available at www.int-res.com/articles/suppl/m411 p089_supp.pdf). Using empirical estimates of withintreatment variability and assuming a power of 0.8 (Magid et al. 1985), I found that this experiment would have been able to detect modest caging treatment effects, quantified as \% change in mean abundance of $B$. violaceus at 3 sites (effect at Wayne $\approx 15 \%$, Pleasant $\approx 15 \%$, Lopez $\approx 25 \%$ ), but high variability at Makah resulted in an ability to detect only relatively large effects (Makah $\approx 50 \%$ ). At Makah, during most census dates, $B$. violaceus abundance tends to be lower when large enemies are absent (see Fig. 3m), so it is very possible that this experiment failed to detect a significant, positive effect of large enemies at this site. Effects were generally larger for the most common native species $($ Makah $\approx 38 \%$, Wayne $\approx 30 \%$, Pleasant $\approx 35 \%$, Lopez $\approx 30 \%$ ) than for the second most common native species (Makah $\approx 23 \%$, Wayne $\approx 19 \%$, Pleasant $\approx 22 \%$, Lopez $\approx 17 \%$ ). I was still able to detect a significant effect of caging treatment on the most common native species at Makah, highlighting the strong effects of large enemies on native species at this site. In summary this power analysis revealed that enemy exclusion effects $<19$ to $50 \%$ of the mean abundance may have gone undetected on any given census date. From the raw data (Fig. 3), it appears that low power of the experiment at Makah may have missed a significant positive effect of large enemies on $B$. violaceus abundance (i.e. apparent competition), and therefore underestimated the role of enemy release at Makah. 
A second explanation for negligible large enemy effects on fouling communities is that micro-predators or parasites, and not large enemies, are controlling agents in this system. A diverse suite of small invertebrates and parasites harm or kill fouling organisms (Poulin \& Chappell 2004, Lambert 2005, Wulff 2006, Lidgard 2008), especially juveniles (Osman et al. 1992, Hunt \& Scheibling 1997). These small enemies were not manipulated in this study because they are not readily visible and because their taxonomy and ecology are not well understood. However, the enemy survey did find that the small mollusk and flatworm functional groups were most abundant at the 2 sites with less large mollusk biomass (Fig. 1), Pleasant and Lopez, where they could be controlling fouling species. A comparative study of small mollusk, flatworm or parasite effects on coexisting native and exotic species or between populations of the same species in native and introduced ranges would help us to better evaluate the role of enemy release in fouling communities.

Finally, the inverted or vertical orientation of fouling communities on anthropogenic substrates may exclude some important native enemies of sessile marine invertebrates. In this study, grazing sea urchins of the genus Strongylocentrotus were low in abundance compared to natural subtidal substrates (Pfister \& Bradbury 1996). The relative predation intensity on anthropogenic and natural hard substrates is relatively unexplored, but predation intensity is likely higher on natural substrates. This may explain why large enemies are relatively less important to fouling communities on anthropogenic substrates, and may represent a key difference between these 2 habitats that are otherwise very similar.

In conclusion, experimental tests of the enemy release hypothesis are currently under-represented outside of the terrestrial plant literature, thus preventing unbiased assessment of its overall merit (Coulatti et al. 2004). This field experiment demonstrates that large enemy release is unlikely to be an important mechanism for exotic species success in Washington fouling communities, except possibly at sites where enemy abundance is very high. Future studies of native populations of exotic marine species and micropredator effects in fouling communities would greatly benefit our ability to evaluate enemy release in benthic marine systems.

Acknowledgements. This research greatly benefited from advice from C. Pfister, T. Wootton, S. Lidgard, M. Fitzsimons, J. Voight and 5 reviewers. Many thanks to Makah Marina and the Makah Nation, Lopez Island Marine Center, John Wayne Marina and Pleasant Harbor Marina for permission to conduct field work. This research was supported by an EPA-STAR fellowship, NSF-DDIG grant, University of Chicago Hinds Fund and a DOE-GAANN graduate fellowship.

\section{LITERATURE CITED}

Agrawal AA, Kotanen PM (2003) Herbivores and the success of exotic plants: a phylogenetically controlled experiment. Ecol Lett 6:712-715

Cohen AN (2004) An exotic species detection program for Puget Sound. National Estuary Program, U.S. Environmental Protection Agency

Colautti RI, Ricciardi A, Grigorovich IA, MacIsaac HJ (2004) Is invasion success explained by the enemy release hypothesis? Ecol Lett 7:721-733

Connell SD (2001) Predatory fish do not always affect the early development of epibiotic assemblages. J Exp Mar Biol Ecol 260:1-12

Crawley MJ (1989) The relative importance of vertebrate and invertebrate herbivores in plant population dynamics. In: E.A. Bernays (ed) Insect-plant interactions. CRC Press, Boca Raton, FL

Darwin C (1859) On the origin of species by means of natural selection. John Murray, London

Elton CS (1958) The ecology of invasions by animals and plants. Methuen, London

Epelbaum A, Pearce CM, Barker DJ, Paulson A, Therriault TW (2009) Susceptibility of non-indigenous ascidian species in British Columbia (Canada) to invertebrate predation. Mar Biol 156:1311-1320

> Faith DP, Minchin PR, Belbin L (1987) Compositional dissimilarity as a robust measure of ecological distance. Vegetatio 69:57-68

Gollan JR, Wright JT (2006) Limited grazing pressure by native herbivores on the invasive seaweed Caulerpa taxifolia in a temperate Australian estuary. Mar Freshw Res 57:685-694

> Grey EK (2009a) Do we need to jump in? A comparison of two survey methods of exotic ascidians on docks. Aquat Invasions 4:81-86

Grey EK (2009b) Scale-dependent relationships between native richness, resource stability and exotic cover in dock fouling communities of Washington, USA. Divers Distrib 15:1073-1080

> Hanski I, Hansson L, Henttonen H (1991) Specialist predators, generalist predators, and the microtine rodent cycle. J Anim Ecol 60:353-367

Hixon MA, Carr MH (1997) Synergistic predation, density dependence, and population regulation in marine fish. Science 277:946-949

Holt RD (1977) Predation, apparent competition, and the structure of prey communities. Theor Popul Biol 12: $197-229$

Huffaker CB, van de Vrie M, McMurtry JA (1970) Ecology of tetranychid mites and their natural enemies: a review. II. Tetranychid populations and their possible control by predators: an evaluation. Hilgardia 40:391-458

> Hunt HL, Scheibling RE (1997) The role of early post-settlement mortality in recruitment of benthic marine invertebrates. Mar Ecol Prog Ser 155:269-301

> Karlson RH (1978) Predation and space utilization patterns in a marine epifaunal community. J Exp Mar Biol Ecol 31: 225-239

Keane RM, Crawley MJ (2002) Exotic plant invasions and the enemy release hypothesis. Trends Ecol Evol 17:164-170

Keough MJ, Butler AJ (1979) The role of asteroid predators in the organization of a sessile community on pier pilings. Mar Biol 51:167-177

Lambert G (2005) Ecology and natural history of the protochordates. Can J Zool 83:34-50

Lambert G, Sanamyan KE (2001) Distaplia alaskensis sp.nov. 
(Ascidiacea, Aplousobranchia) and other new ascidian records from south-central Alaska, with a redescription of Ascidia columbiana (Huntsman, 1912). Can J Zool 79: 1766-1781

Lidgard SL (2008) Predation on marine bryozoan colonies: taxa, traits and trophic groups. Mar Ecol Prog Ser 359: $117-131$

Liu H, Stiling P (2006) Testing the enemy release hypothesis: a review and meta-analysis. Biol Invasions 8:1535-1545

Lubchenco J (1978) Plant species diversity in a marine intertidal community: importance of herbivore food preference and algal competitive abilities. Am Nat 112:23-39

Mack RN, Simberloff D, Lonsdale WM, Evans H, Clout M, Bazzaz FA (2000) Biotic invasions: causes, epidemiology, global consequences and control. Ecol Appl 10:689-710

Mazen MA, Hemmasi M, Lewis, MF (1985) In search of power: a statistical power analysis of contemporary research in strategic management. Academy of Management Proceedings, New York, p 30-34

Mitchell CE, Power AG (2003) Release of invasive plants from fungal and viral pathogens. Nature 421:625-627

Molnar JL, Gamboa RL, Revenga C, Spalding MD (2008) Assessing the global threat of invasive species to marine biodiversity. Front Ecol Environ 6:485-492

> Nydam M, Stachowicz JJ (2007) Predator effects on fouling community development. Mar Ecol Prog Ser 337:93-101

Oksanen J, Kindt R, Legendre P, O'Hara B and others (2009) Vegan: community ecology package. $\mathrm{R}$ package version 1.15-4, available at http://CRAN.R-project.org/package= vegan

Osman RW, Whitlatch RB (1995) Predation on early ontogenetic life-stages and its effect on recruitment into a marine community. Mar Ecol Prog Ser 117:111-126

Osman RW, Whitlatch RB (2004) The control of the development of a marine benthic community by predation on adults. J Exp Mar Biol Ecol 311:117-145

Osman RW, Whitlatch RB, Malatesta RJ (1992) Potential role of micro-predators in determining recruitment into a marine community. Mar Ecol Prog Ser 83:35-43

Paine RT (1974) Intertidal community structure: experimental studies on the relationship between a dominant competitor and its principal predator. Oecologia 15:93-120

Pfister CA, Bradbury A (1996) Harvesting red sea urchins: recent effects and future predictions. Ecol Appl 6:298-310

Poulin R, Chappell LH (eds) 2004. Parasites in marine systems. Cambridge University Press, Cambridge
Ruiz GM, Carlton JT (2003) Invasive species: vectors and management strategies. Islander Press, Washington, DC

Sams MA, Keough MJ (2007) Predation during early postsettlement varies in importance for shaping marine sessile communities. Mar Ecol Prog Ser 348:85-101

Shinen JS, Morgan SG, Chan AL (2009) Invasion resistance on rocky shores: direct and indirect effects of three native predators on an exotic and a native prey species. Mar Ecol Prog Ser 378:47-54

Simoncini M, Miller RJ (2007) Feeding preferences of Stronglyocentrotus droebachiensis (Echinoida) for a dominant native ascidian, Aplidium glabrum, relative to the invasive ascidian Botrylloides violaceus. J Exp Mar Biol Ecol 342:93-98

> Steneck RS, Watling L (1982) Feeding capabilities and limitation of herbivorous mollusks: a functional group approach. Mar Biol 68:299-319

Stoner DS (1990) Recruitment of a tropical colonial ascidian: relative importance of pre-settlement and post-settlement processes. Ecology 71:1682-1690

Strong JA, Maggs CA, Johnson MP (2009) The extent of grazing release from epiphytism for Sargassum muticum (Phaeophyceae) within the invaded range. J Mar Biol Assoc UK 89:303-314

Sutherland JP (1974) Multiple stable points in natural communities. Am Nat 108:859-873

Tansley AG, Adamson RS (1925) Studies of the vegetation of the English chalk. III. The chalk grasslands of the Hampshire-Sussex border. J Ecol 13:177-223

> Torchin ME, Lafferty KD, Kuris AM (2002) Parasites and marine invasions. Parasitology 124:S137-S151

Underwood AJ (1997) Experiments in ecology: their logical design and interpretation using analysis of variance. Cambridge University Press, Cambridge

> Vance RR (1988) Ecological succession and the climax community on a marine subtidal rock wall. Mar Ecol Prog Ser 48:125-136

Vignon M, Sasal P, Gatzin R (2009) Host introduction and parasites: a case study on the parasite community of the peacock grouper Cephalopholis argus (Serranidae) in the Hawaiian Islands. Parasitol Res 104:775-782

Williamson M (1996) Biological Invasions. Chapman \& Hall, London

- Wolfe LM (2002) Why alien invaders succeed: support for the escape-from-enemy hypothesis. Am Nat 160:705-722

> Wulff JL (2006) Ecological interactions of marine sponges. Can J Zool 84:146-166 
Appendix 1. ANOVA of cage treatment effects on recruitment and abundance of Botrylloides violaceus and native species, and on number of large and small $B$. violaceus colonies

Table A1. Repeated-measures ANOVA of the effects of cage treatment (Cage Trt) and census date (Date) on recruitment rate and abundance of Botrylloides violaceus and the 2 most abundant native species, tested with with Plate as a random effect. Recruitment rate was quantified as mean no. of new recruits, and abundance as mean number of individuals on a plate at each census. Data log-transformed prior to analysis; ${ }^{*} \mathrm{p}<0.05,{ }^{* *} \mathrm{p}<0.01,{ }^{* * *} \mathrm{p}<0.0001$

\begin{tabular}{|c|c|c|c|c|c|c|c|c|c|c|c|c|}
\hline \multirow{2}{*}{$\begin{array}{l}\text { Site } \\
\quad \text { Effect }\end{array}$} & \multicolumn{4}{|c|}{ Exotic species } & \multicolumn{4}{|c|}{ 1st native species } & \multicolumn{4}{|c|}{ 2nd native species } \\
\hline & df & SS & $F$ & $\mathrm{p}$ & df & SS & $F$ & $\mathrm{p}$ & $\mathrm{df}$ & SS & $F$ & $\mathrm{p}$ \\
\hline \multicolumn{13}{|l|}{ Recruitment rate } \\
\hline Makah & \multicolumn{4}{|c|}{ (a) B. violaceus } & \multicolumn{4}{|c|}{ (b) Obelia sp. } & \multicolumn{4}{|c|}{ (c) Distaplia occidentalis } \\
\hline Cage Trt & 2 & 3.99 & 0.51 & 0.603 & 2 & 1.39 & 0.67 & 0.510 & 2 & 2.64 & 1.03 & 0.360 \\
\hline Date & 7 & 468.66 & 17.01 & $<0.001^{* * *}$ & 6 & 29.49 & 4.72 & $0.003^{* * *}$ & 5 & 205.63 & 36.74 & $<0.001^{* * *}$ \\
\hline Cage Trt $\times$ Date & 14 & 84.18 & 1.53 & 0.108 & 12 & 14.73 & 1.18 & 0.310 & 10 & 6.43 & 0.57 & 0.830 \\
\hline Residuals & 144 & 620.99 & & & 120 & 142.23 & & & 102 & 138.56 & & \\
\hline Wayne & \multicolumn{4}{|c|}{ (d) B. violaceus } & \multicolumn{4}{|c|}{ (e) Distaplia occidentalis } & \multicolumn{4}{|c|}{ (f) Corella inflata } \\
\hline Cage Trt & 2 & 0.10 & 0.09 & 0.910 & 2 & 0.28 & 0.18 & 0.840 & 2 & 0.21 & 0.16 & 0.855 \\
\hline Date & 6 & 333.90 & 106.41 & $<0.001^{* * *}$ & 6 & 160.18 & 48.45 & $<0.001^{* * *}$ & 6 & 151.34 & 37.51 & $<0.001^{* * *}$ \\
\hline Cage Trt $\times$ Date & 12 & 2.54 & 0.41 & 0.960 & 12 & 6.69 & 1.03 & 0.429 & 12 & 1.79 & 0.22 & 0.997 \\
\hline Residuals & 123 & 70.41 & & & 123 & 75.45 & & & 123 & 98.80 & & \\
\hline Pleasant & \multicolumn{4}{|c|}{ (q) B. violaceus } & \multicolumn{4}{|c|}{ (h) Mytilus edulis } & \multicolumn{4}{|c|}{ (i) Corella inflata } \\
\hline Cage Trt & 2 & 1.42 & 0.37 & 0.695 & 2 & 5.94 & 2.12 & 0.132 & 2 & 5.93 & 1.99 & 0.161 \\
\hline Date & 5 & 167.43 & 17.40 & $<0.001^{* * *}$ & 5 & 16.05 & 2.83 & $0.021^{*}$ & 1 & 0.11 & 0.08 & 0.785 \\
\hline Cage $\operatorname{Trt} \times$ Date & 10 & 12.45 & 0.65 & 0.770 & 10 & 9.82 & 0.87 & 0.566 & 2 & 9.18 & 3.08 & 0.067 \\
\hline Residuals & 102 & 209.70 & & & 102 & 136.31 & & & 42 & 45.08 & & \\
\hline Lopez & \multicolumn{4}{|c|}{ (j) B. violaceus } & \multicolumn{4}{|c|}{ (k) Corella inflata } & \multicolumn{4}{|c|}{ (l) Distaplia occidentalis } \\
\hline Cage Trt & 2 & 2.66 & 0.51 & 0.603 & 2 & 35.12 & 6.56 & $0.002^{* *}$ & 2 & 2.58 & 1.02 & 0.313 \\
\hline Date & 7 & 756.91 & 45.19 & $<0.001^{* * *}$ & 6 & 214.01 & 13.32 & $<0.001^{* * *}$ & 5 & 76.18 & 13.89 & $<0.001^{* * *}$ \\
\hline Cage Trt $\times$ Date & 14 & 44.26 & 1.32 & 0.202 & 12 & 43.84 & 1.36 & 0.192 & 10 & 10.75 & 0.98 & 0.466 \\
\hline Residuals & 144 & 387.53 & & & 123 & 393.86 & & & 102 & 123.96 & & \\
\hline \multicolumn{13}{|l|}{ Abundance } \\
\hline Makah & \multicolumn{4}{|c|}{ (m) B. violaceus } & \multicolumn{4}{|c|}{ (n) Obelia sp. } & \multicolumn{4}{|c|}{ (o) Distaplia occidentalis } \\
\hline Cage Trt & 2 & 1.32 & 0.69 & 0.514 & 2 & 9.49 & 3.75 & $0.041^{*}$ & 2 & 0.61 & 0.32 & 0.727 \\
\hline Date & 6 & 44.42 & 7.68 & $<0.001^{* * *}$ & 6 & 229.5 & 30.23 & $<0.001^{* * *}$ & 7 & 86.46 & 13.22 & $<0.001^{* * *}$ \\
\hline Cage Trt $\times$ Date & 12 & 8.2 & 0.71 & 0.730 & 12 & 10.74 & 0.71 & 0.742 & 14 & 4.44 & 0.34 & 0.988 \\
\hline Residuals & 123 & 123.9 & & & 123 & 165.97 & & & 144 & 139.19 & & \\
\hline Wayne & & (p) $B . v$ & violaceus & & (q & Distapli & a occides & ntalis & & (r) Core & a inflat & \\
\hline Cage Trt & 2 & 0.07 & 0.50 & 0.615 & 2 & 0.52 & 2.14 & 0.141 & 2 & 21.92 & 3.58 & $0.029^{*}$ \\
\hline Date & 6 & 7.32 & 16.60 & $<0.001^{* * *}$ & 6 & 17.00 & 15.01 & $<0.001^{* * *}$ & 6 & 759.7 & 55.88 & $<0.001^{* * *}$ \\
\hline Cage Trt $\times$ Date & 12 & 0.93 & 1.06 & 0.404 & 12 & 0.76 & 0.62 & 0.820 & 12 & 47.39 & 1.15 & 0.127 \\
\hline Residuals & 123 & 9.48 & & & 123 & 14.73 & & & 123 & 339.08 & & \\
\hline Pleasant & & (s) $B . v$ & violaceus & & & (t) Mytilu & us trossu & lus & & (u) Core & a inflat & \\
\hline Cage Trt & 2 & 0.44 & 1.27 & 0.380 & 2 & 0.85 & 1.05 & 0.367 & 2 & 39.69 & 0.36 & 0.705 \\
\hline Date & 5 & 53.58 & 61.46 & $<0.001^{* * *}$ & 1 & 58.53 & 145.51 & $<0.001^{* * *}$ & 2 & 3424 & 31.18 & $<0.001^{* * *}$ \\
\hline Cage Trt $\times$ Date & 10 & 1.07 & 0.61 & 0.772 & 2 & 1.93 & 2.40 & 0.115 & 4 & 219.1 & 1.00 & 0.421 \\
\hline Residuals & 102 & 19.99 & & & 18 & 14.49 & & & 39 & 3451 & & \\
\hline Lopez & & (v) B. v & violaceus & & & (w) Core & ella infla & & $(\mathrm{x})$ & Distaplia & occider & talis \\
\hline Cage Trt & 2 & 0.13 & 0.41 & 0.663 & 2 & 2.86 & 2.66 & 0.075 & 2 & 0.92 & 0.89 & 0.414 \\
\hline Date & 7 & 24.22 & 21.31 & $<0.001^{* * *}$ & 5 & 14.96 & 5.56 & $<0.001^{* * *}$ & 7 & 8.30 & 1.63 & 0.134 \\
\hline Cage $\operatorname{Trt} \times$ Date & 14 & 7.67 & 3.37 & $0.001^{* * *}$ & 10 & 7.16 & 1.33 & 0.226 & 14 & 4.28 & 0.65 & 0.821 \\
\hline Residuals & 130 & 22.34 & & & 92 & 54.90 & & & 130 & 53.10 & & \\
\hline
\end{tabular}


Table A2. 1-way ANOVA of the effects of Cage treatment (Cage Trt) on mean number of large and small Botrylloides violaceus colonies

\begin{tabular}{|c|c|c|c|c|c|c|c|c|}
\hline \multirow[t]{2}{*}{ Site } & \multirow[t]{2}{*}{ Effect } & \multirow[b]{2}{*}{$\mathrm{df}$} & \multicolumn{3}{|c|}{ Large colonies } & \multicolumn{3}{|c|}{ Small colonies } \\
\hline & & & SS & $F$ & $\mathrm{p}$ & SS & $F$ & $\mathrm{p}$ \\
\hline \multirow[t]{2}{*}{ Makah } & Cage Trt & 2 & 0.17 & \multirow[t]{2}{*}{0.19} & \multirow[t]{2}{*}{0.828} & 1.05 & \multirow[t]{2}{*}{0.80} & \multirow[t]{2}{*}{0.464} \\
\hline & Residuals & 21 & 9.20 & & & 13.76 & & \\
\hline \multirow[t]{2}{*}{ Wayne } & Cage Trt & 2 & 0.15 & \multirow[t]{2}{*}{0.47} & \multirow[t]{2}{*}{0.629} & 164.21 & \multirow[t]{2}{*}{0.41} & \multirow[t]{2}{*}{0.667} \\
\hline & Residuals & 21 & 3.36 & & & 4181.12 & & \\
\hline \multirow[t]{2}{*}{ Pleasant } & Cage Trt & 2 & 0.88 & \multirow[t]{2}{*}{0.86} & \multirow[t]{2}{*}{0.437} & 58.56 & \multirow[t]{2}{*}{0.50} & \multirow[t]{2}{*}{0.612} \\
\hline & Residuals & 21 & 10.72 & & & 1222.18 & & \\
\hline \multirow[t]{2}{*}{ Lopez } & Cage Trt & 2 & 0.23 & \multirow[t]{2}{*}{0.76} & \multirow[t]{2}{*}{0.481} & 34.20 & \multirow[t]{2}{*}{0.91} & \multirow[t]{2}{*}{0.420} \\
\hline & Residuals & 17 & 2.52 & & & 318.41 & & \\
\hline
\end{tabular}

Editorial responsibility: Richard Osman,

Edgewater, Maryland, USA
Submitted: February 2, 2010; Accepted: April 29, 2010

Proofs received from author(s): July 8, 2010 